\title{
A Reevaluation of the National Emission Standards for Hazardous Air Pollutants (NESHAP - 40 CFR 61, Subpart H) Program at Sandia National Laboratories, New Mexico CONF-98020Z - -
}

T.A. Culp, Sandia National Laboratories, P.O. Box 5800, MS-0854, Albuquerque, NM 87185. Phone: 505-845-7886, Fax: 505-845-7154, E-Mail: <taculp@envc.sandia.gov>

J.M. Hylko, Roy F. Weston, Inc., 6501 Americas Parkway NE, Suite 800 , Albuquerque, NM 87110. Phone: 505-845-7894, Fax: 505-837-6870, E-Mail: OCT 151997 $<$ JHylko@msn.com>

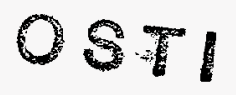

\section{Abstract}

The initial National Emission Standards for Hazardous Air Pollutants (NESHAP - 40 CFR 61, Subpart H) Program at Sandia National Laboratories, New Mexico (SNL/NM) required: 1) continuous air monitoring of sources if the calculated effective dose equivalent (EDE) to the maximum exposed individual (MEI) was $>0.1 \mathrm{mrem} / \mathrm{yr} ; 2)$ the determination of emissions based on measurements or measured parameters (e.g., periodic confirmatory measurements) if the EDE to the MEI was $<0.1 \mathrm{mrem} / \mathrm{yr}$; and 3) the calculation of worst case releases when the expected air concentrations were below detection limits using standard monitoring equipment. This conservative interpretation of the regulation guided SNL/NM to model, track, and trend virtually all emission sources with the potential to include any radionuclides. The level of effort required to implement these activities was independent of the EDE contributing from individual sources. A recent programmatic review found the NESHAP program to be in excess of the legal requirements. A further review found that, in summation, 13 of 16 radionuclide sources (approximately $81 \%$ ) had a negligible impact on the final calculated EDE to the MEI used to demonstrate compliance at 20 separate on-site receptor locations. A reevaluation was performed to meet the legal requirements of $40 \mathrm{CFR} 61$, Subpart $\mathrm{H}$, and still be reasonable and appropriate under the existing circumstances. The distinction is that, by regulation, monitoring systems will not be required if the EDE to the MEI is $<0.1$ $\mathrm{mrem} / \mathrm{yr}$, and worst case release calculations will not be performed. The new method of modeling, tracking, and trending the EDE to the MEI will consist of: 1) continuous monitoring if the EDE to the MEI is $>0.1 \mathrm{mrem} / \mathrm{yr}$; and 2) no monitoring requirements of any source if the EDE to the MEI is $<0.1 \mathrm{mrem} / \mathrm{yr}$. However, if monitoring is performed, the results will reported to verify compliance with the $10 \mathrm{mrem} / \mathrm{yr}$ NESHAP standard. All other sources not having the potential to emit significant concentrations of radionuclides will also be listed in the annual NESHAP report regardless of impact to the MEI. This reevaluation promotes the effective allocation of resources to those emission sources contributing the majority of the EDE to the MEI.

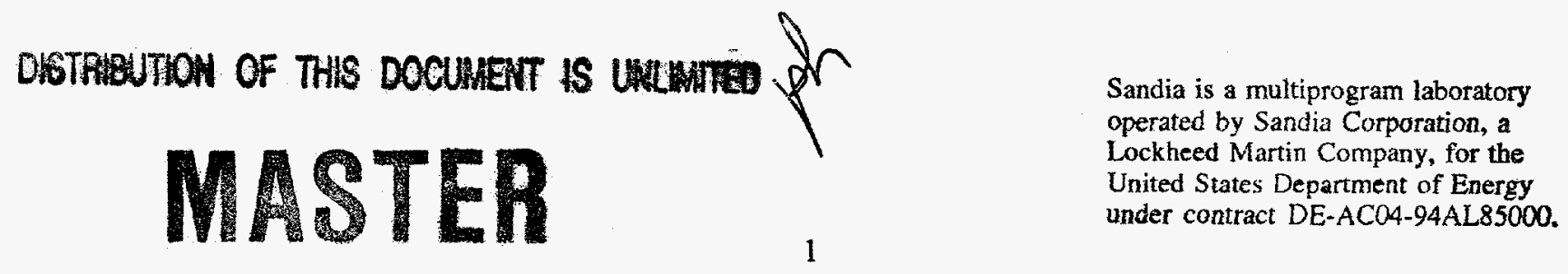




\section{DISCLAIMER}

This report was prepared as an account of work sponsored by an agency of the United States Government. Neither the United States Government nor any agency thereof, nor any of their employees, makes any warranty, express or implied, or assumes any legal liability or responsibility for the accuracy, completeness, or usefulness of any information, apparatus, product, or process disclosed, or represents that its use would not infringe privately owned rights. Reference herein to any specific commercial product, process, or service by trade name, trademark, manufacturer, or otherwise does not necessarily constitute or imply its endorsement, recommendation, or favoring by the United States Government or any agency thereof. The views and opinions of authors expressed herein do not necessarily state or reflect those of the United States Government or any agency thereof. 


\section{DISCLAIMER}

Portions of this document may be illegible electronic image products. Images are produced from the best available original document. 


\section{Introduction}

In 1989, the Environmental Protection Agency (EPA) promulgated Title 40 of the Code of Federal Regulations, Part 61, Subpart H, (40 CFR 61, Subpart H) National Emission Standards for Emissions of Radionuclides Other Than Radon from Department of Energy Facilities (NESHAP) (EPA 1989) to address air emissions of radionuclides, excluding radon, from Department of Energy facilities. Specifically, Part 61.92 states that "Emissions of radionuclides to the ambient air from Department of Energy facilities shall not exceed those amounts that would cause any member of the public to receive in any year an effective dose equivalent (EDE) of $10 \mathrm{mrem} / \mathrm{yr}$." As a result, the initial NESHAP program at Sandia National Laboratories, New Mexico (SNL/NM) required the following:

1. Continuous air monitoring of sources if the calculated EDE to the maximum exposed individual (MEI) was $>0.1 \mathrm{mrem} / \mathrm{yr}$.

2. The determination of emissions based on measurements or measured parameters (e.g., periodic confirmatory measurements) if the EDE was $<0.1 \mathrm{mrem} / \mathrm{yr}$.

3. The calculation of worst case releases when the expected air concentrations were below detection limits using standard monitoring equipment.

This conservative interpretation of the regulation guided SNL/NM to model, track, and trend virtually all emission sources with the potential to include any radionuclides. The level of effort required to implement these activities was independent of the EDE contributing from individual sources. A reevaluation was performed to meet the legal requirements of $40 \mathrm{CFR}$ 61, Subpart $\mathrm{H}$, and still be reasonable and appropriate under the existing circumstances. The purpose of this paper is to summarize the regulatory requirements associated with the SNL/NM NESHAP program, identify the primary source term contributors, and use this information to reevaluate the reporting of emission sources contributing the majority of the EDE to the MEI.

\section{Regulatory Requirements}

As summarized in 40 CFR 61.94, Compliance and Reporting, compliance is determined by calculating the EDE to the MEI. The owners or operators of each facility must submit an annual report to both EPA headquarters and the appropriate regional office by June 30 of the following calendar year. This submittal includes the results of the of monitoring results recorded in DOE's Effluent Information System (DOE 1980), and the dose calculations required by Part 61.93(a) for the previous calendar year. To determine compliance with the standard, Part 61.93(a) requires that radionuclide emissions and the EDE to the MEI must be calculated using EPA-approved sampling procedures, computer models (e.g., CAP88-PC (EPA 1992)), or other procedures granted prior approval by the EPA.

According to Part 61.93(b)(4)(i), radionuclide emission measurements must be made at all release points having the potential to discharge radionuclides into the air in quantities 
that could cause an EDE to the MEI to exceed $0.1 \mathrm{mrem} / \mathrm{yr}$. For quantities resulting in less than $0.1 \mathrm{mrem} / \mathrm{yr}$, periodic confirmatory measurements are to confirm low emissions. Part 61.93(b)(4)(ii) outlines the process for determining whether a release point is subject to the emission measurement requirements.

DOE's Effluent Information System requires an annual submittal of form DOE F-5821.1 (Rev. 11/80), Radioactive Effluent/Onsite Discharges/Unplanned Releases (DOE 1980). Guidance for the preparation of this report requires the inclusion of data generated only through the use of monitoring systems (instruction $2 ; 4-5,23-80$ ). Calculated results are also included in the report. The information is submitted to the Idaho National Engineering and Environmental Laboratory by April 1 of the following calendar year.

A Memorandum of Understanding (MOU) between EPA and DOE, Memorandum of Understanding with the Environmental Protection Agency Concerning the Radionuclide National Emission Standards for Hazardous Air Pollutants, dated April 5, 1995 (DOE 1995), addresses the subject of small emission sources. The MOU describes minor emission sources as sources with the potential to discharge radionuclides into the air, without effluent controls in place, resulting in an EDE to the MEI of less than 0.1 $\mathrm{mrem} / \mathrm{yr}$. As stated in Part 61.94(b), these sources are required to be listed in the annual NESHAP report. Additional information such as identification numbers, types, and quantities of radionuclides emitted must be available for review upon request by EPA.

By considering all regulatory requirements required by the SNL/NM NESHAP program, monitoring was required of radionuclide sources resulting in a potential EDE to the MEI of greater than $0.1 \mathrm{mrem} / \mathrm{yr}$ as determined using the guidance found in Part 61.93(b). To document compliance, radionuclide air emissions from all 16 sources were modeled to each of the 28 on-site and off-site MEI receptors. Since the total EDE to an individual MEI receptor is the sum of the contributions from each of the 16 individual radionuclide sources, 448 model runs were performed accordingly.

Sources with monitored and calculated data were also included in DOE's Effluent Information System report. This data was then used to determine compliance with the 10 mrem/yr NESHAP standard using guidance found in Part 61.93(a). Sources with a potential EDE to the MEI of less than $0.1 \mathrm{mrem} / \mathrm{yr}$ neither required monitoring systems nor inclusion in the DOE's Effluent Information System. In addition, calculations were not required to demonstrate compliance using part 61.93(a). However, these sources were still identified and listed in the annual NESHAP report, and information specifically related to potential radionuclide emissions were documented and made available for review upon request by EPA.

\section{Primary Source Term Contributors}

Four years (1993 through 1996) of radiological data consisting of annual EDEs to the MEIs from 16 radionuclide sources for 20 on-site receptor locations were compiled for this evaluation. The remaining 8 off-site receptor locations were not included in this 
evaluation. Over this period, the mean EDE was $2.65 \mathrm{E}-03 \mathrm{mrem} / \mathrm{year}$, ranging from $8.54 \mathrm{E}-04 \mathrm{mrem} /$ year in 1995 to $7.01 \mathrm{E}-03 \mathrm{mrem} / \mathrm{year}$ in 1996. The increase in the EDE for 1996 was attributable to increased emissions from the Annular Core Research Reactor (ACRR) and the Hot Cell Facility (HCF).

Of the 16 radionuclide sources reporting emissions in 1996, the ACRR contributed approximately $77 \%$ of the total annual EDE to on-site receptors. The primary radionuclide contributing to the source term in Curies per year was Ar-41. The Sandia Pulsed Reactor (SPR) contributed approximately $17 \%$, also from Ar- 41 . The HCF, which started operation in 1996, contributed less than $6 \%$, primarily from noble gases. All other facilities in operation contributed to less than $1 \%$ of the total annual EDE.

Of the 12 radionuclide sources reporting emissions in 1995, the ACRR contributed approximately $70 \%$ of the total annual EDE to on-site receptors. The primary radionuclide contributing to the source term in Curies per year was Ar-41. The SPR contributed approximately $29 \%$, also from Ar-41. All other facilities in operation contributed to less than $1 \%$ of the total annual EDE.

Of the 11 radionuclide sources reporting emissions in 1994, the ACRR and SPR contributed approximately $47 \%$ each to the total annual EDE to on-site receptors, including contributions of $2.7 \%$ each, from the High Energy Radiation Megavolt Electron Source (HERMES-III) and the Particle Beam Fusion Accelerator-II (PBFA-II). The primary radionuclide contributing to the source term in Curies per year from the ACRR and SPR was Ar-41. The primary radionuclides contributing to the source term in Curies per year from HERMES and PBFA-II were from air activation products. All other facilities in operation contributed to less than $1 \%$ of the total annual EDE.

Of the 8 radionuclide sources reporting emissions in 1993, the ACRR contributed approximately $95 \%$ to the total annual EDE to on-site receptors. The primary radionuclide contributing to the source term in Curies per year was from Ar-41. The SPR contributed approximately $3.5 \%$ from $\mathrm{Ar}-41$. All other facilities in operation contributed to less than $1 \%$ of the total annual EDE.

The information demonstrates that the site-wide cumulative EDE to the MEI has always been less than the $10 \mathrm{mrem} / \mathrm{yr}$ standard. In many cases, the smaller source contribution to the EDE never even impacted the least significant figure of the final EDE to the MEI.

\section{Reevaluating the SNL/NM NESHAP Program}

In 1996, the NESHAP report included results consisting of 28 on-site and off-site receptors and 16 facilities. Only 6 radionuclide sources reported air emissions based on measurements or measured parameters. Some of the facilities reported data due to Part 61.93(b)(4)(ii) requirements, and others reported data as part of best management practices. The remainder of the radionuclide sources reported emissions based on worst- 
case calculations. Tables $1 \mathrm{a}$ and $1 \mathrm{~b}$ list the annual effective dose equivalent to 20 on-site MEI receptors from all 16 sources.

(Tables $1 \mathrm{a}$ and $1 \mathrm{~b}$ - Attached)

For the purposes of modeling, tracking, and trending EDE to the MEI, interacting with source owners, and whether the resulting EDE is large or small, the same amount of effort is expended by NESHAP personnel. Since the SNL/NM current NESHAP program was already in excess of the requirements of 40 CFR 61 , Subpart $H$, it would appear to be reasonable, appropriate, and legal to limit the number of radionuclide sources reported based on either measurements or measured parameters in the annual NESHAP report.

The new method of modeling, tracking, and trending the EDE to the MEI will consist of:

1. Continuous monitoring if the EDE to the MEI is $>0.1 \mathrm{mrem} / \mathrm{yr}$.

2. No monitoring requirements of any source if the EDE to the MEI is $<0.1 \mathrm{mrem} / \mathrm{yr}$.

Therefore, under the revised SNL/NM NESHAP reporting program, modeling radionuclide emissions from 6 sources to each of the 28 on-site and off-site receptors would require only 168 model runs. Table 2 lists the annual effective dose equivalent to 20 on-site MEI receptors from 6 sources. Furthermore, Table 2 demonstrates how these 6 sources contribute over $98 \%$ of the total EDEs to the individual receptors.

(Table 2 - Attached)

Sources that do not generate data acquired either from measurements or measured parameters would still meet the requirements of 61.93 (a) by being listed in the annual NESHAP report regardless of impact to the MEI. At a minimum, the listing would include the source's name and location. Information specifically related to the potential radionuclide emissions would be the responsibility of the source owner. However, if monitoring is performed, the results will reported to verify compliance with the $10 \mathrm{mrem} / \mathrm{yr}$ NESHAP standard.

\section{Conclusion}

Resources were made available to SNL/NM for compliance activities associated with implementing a new NESHAP regulation. The requirements of 40 CFR 61, Subpart H were intended to limit the potential dose to members of the public resulting from the emission of radionuclides in the air from DOE facilities. However, it was difficult to envision the true impression and implications of a new regulation without actual operating experience.

A recent reevaluation found the SNL/NM NESHAP program to be in excess of the existing legal requirements. This reevaluation uncovered many differences when 
compared to the initial, and conservative interpretation of 40 CFR 61, Subpart $\mathrm{H}$, that previously resulted in SNL/NM prescribing to excessive programmatic requirements. This conservative interpretation was due in part to SNL/NM not fully understanding its radionuclide source term, their potential dose impact to the MEI as it related to the regulation, and limited amount of time to attain NESHAP compliance. A further review found that in summation, 13 of 16 radionuclide sources (approximately 81\%) monitored in 1996 had negligible impact of the final calculated EDE to the MEI.

By acquiring a greater understanding of its potential radionuclide source term, including monitoring and reporting requirements, $\mathrm{SNL} / \mathrm{NM}$ was able to allocate resources according to those radionuclide sources contributing the majority of the EDE to the MEI. Furthermore, as resources required to maintain compliance activities after implementation are often subject to reduction, this reevaluation also demonstrates how compliance programs should be reviewed and updated annually, and time-consuming process should be eliminated accordingly. Moreover, as operational experience is acquired, decisions should be based on experience and process knowledge rather than relying on conservative assumptions that tend to overestimate the EDE to the MEI.

\section{References}

DOE 1980, DOE F-5821.1 - Radioactive Effluent/Onsite Discharges/Unplanned Releases, U.S. Department of Energy, Washington, DC. November 1980.

DOE 1995, Memorandum of Understanding with the Environmental Protection Agency Concerning the Radionuclide National Emission Standards for Hazardous Air Pollutants, U.S. Department of Energy, Washington, DC. April 5, 1995.

EPA 1989, Title 40 of the Code of Federal Regulations, Part 61, Subpart H, (40 CFR 61, Subpart H) National Emission Standards for Emissions of Radionuclides Other Than Radon from Department of Energy Facilities (NESHAP), U.S. Environmental Protection Agency, Washington, DC. 1989.

EPA 1992, User's Guide for CAP88-PC, Version 1.0, 402-B-92-001, U.S. Environmental Protection Agency, Washington, DC. March 1992. 
Table 1a. Annual Effective Dose Equivalent to On-Site Receptors

Source-Specific Effective Dose Equivalents (mrem/yr)

\begin{tabular}{|c|c|c|c|c|c|c|c|c|c|c|}
\hline Receptor & $\begin{array}{c}\text { Radiation } \\
\text { Lab } \\
\text { (Bldg. 827) }\end{array}$ & $\begin{array}{c}\text { Calibration } \\
\text { Lab } \\
\text { (Bldg. 869) }\end{array}$ & $\begin{array}{c}\text { Neutron } \\
\text { Generator } \\
\text { Facility } \\
\text { (Bldg. 870) }\end{array}$ & $\begin{array}{l}\text { TANDEM } \\
\text { (Bldg. 884) }\end{array}$ & $\begin{array}{c}\text { Metal } \\
\text { Tritide } \\
\text { Lab } \\
\text { (Bldg. } 891 \text { ) }\end{array}$ & $\begin{array}{l}\text { Integrated } \\
\text { Materials } \\
\text { Research } \\
\text { Laboratory } \\
\text { (Bldg. 897) }\end{array}$ & $\begin{array}{c}\text { ECF } \\
\text { (Bldg. 905) }\end{array}$ & $\begin{array}{c}\text { Radioactive } \\
\text { Waste } \\
\text { Landfill }\end{array}$ & $\begin{array}{l}\text { Mixed } \\
\text { Waste } \\
\text { Landfill }\end{array}$ & $\begin{array}{c}\text { Chemical } \\
\text { Processing } \\
\text { Lab } \\
\text { (Bldg. 6600) }\end{array}$ \\
\hline Airport (Building 760) & $2.1 \mathrm{E}-10$ & $5.8 \mathrm{E}-09$ & $7.1 \mathrm{E}-07$ & $2.8 \mathrm{E}-07$ & $7.9 E-14$ & $2.3 \mathrm{E}-11$ & $7.8 \mathrm{E}-09$ & $1.7 \mathrm{E}-11$ & $1.0 \mathrm{E}-06$ & $2.6 \mathrm{E}-12$ \\
\hline Airport East (Building 1064) & $1.6 \mathrm{E}-10$ & 4.2E-09 & $1.3 \mathrm{E}-06$ & $2.3 \mathrm{E}-07$ & $5.9 \mathrm{E}-14$ & $1.5 \mathrm{E}-11$ & 7.5E-09 & $1.3 \mathrm{E}-11$ & 8.4E-07 & $2.1 \mathrm{E}-12$ \\
\hline Building 20706 & 2.0E-09 & $3.6 \mathrm{E}-08$ & $3.5 \mathrm{E}-06$ & $4.8 \mathrm{E}-06$ & $1.5 \mathrm{E}-13$ & $6.5 \mathrm{E}-11$ & $3.4 \mathrm{E}-08$ & $4.0 \mathrm{E}-11$ & 7.9E-07 & $2.7 \mathrm{E}-12$ \\
\hline Building 24499 & $3.0 \mathrm{E}-10$ & $6.2 \mathrm{E}-09$ & $4.0 \mathrm{E}-06$ & $1.4 \mathrm{E}-06$ & $9.0 \mathrm{E}-14$ & $2.9 \mathrm{E}-11$ & $2.6 \mathrm{E}-08$ & $2.7 \mathrm{E}-11$ & $6.1 \mathrm{E}-07$ & $1.7 \mathrm{E}-12$ \\
\hline CERF (Building 5701) & $9.7 \mathrm{E}-12$ & $2.4 \mathrm{E}-10$ & $1.1 \mathrm{E}-07$ & $5.0 \mathrm{E}-09$ & $4.2 \mathrm{E}-15$ & $1.6 \mathrm{E}-12$ & $7.3 \mathrm{E}-10$ & $1.9 \mathrm{E}-12$ & $6.9 \mathrm{E}-07$ & $1.5 \mathrm{E}-12$ \\
\hline Coyote Canyon Control Center & $1.0 \mathrm{E}-11$ & $2.5 \mathrm{E}-10$ & $1.1 E-07$ & $5.4 \mathrm{E}-09$ & $4.4 \mathrm{E}-15$ & $1.7 \mathrm{E}-12$ & $7.7 \mathrm{E}-10$ & $1.9 \mathrm{E}-12$ & $5.6 \mathrm{E}-07$ & $1.5 \mathrm{E}-12$ \\
\hline Golf Course Clubhouse & $4.2 \mathrm{E}-11$ & $1.0 \mathrm{E}-09$ & $4.6 \mathrm{E}-07$ & 5.7E-08 & $1.6 \mathrm{E}-14$ & $6.6 \mathrm{E}-12$ & 3.7E-09 & $1.0 \mathrm{E}-11$ & $2.0 \mathrm{E}-06$ & $9.1 \mathrm{E}-12$ \\
\hline Golf Course Maintenance Area & $6.0 \mathrm{E}-11$ & $1.5 \mathrm{E}-09$ & $6.7 \mathrm{E}-07$ & $1.0 \mathrm{E}-07$ & $2.1 \mathrm{E}-14$ & $9.4 E-12$ & $5.8 \mathrm{E}-09$ & $1.7 \mathrm{E}-11$ & $1.6 \mathrm{E}-06$ & $5.7 \mathrm{E}-12$ \\
\hline ITRI/Lovelace & 8.3E-12 & $2.1 \mathrm{E}-10$ & $9.1 \mathrm{E}-08$ & $3.6 \mathrm{E}-09$ & $3.6 \mathrm{E}-15$ & $1.4 \mathrm{E}-12$ & $6.1 \mathrm{E}-10$ & $1.5 \mathrm{E}-12$ & $5.6 \mathrm{E}-07$ & $1.2 \mathrm{E}-12$ \\
\hline $\begin{array}{l}\text { KAFB Firestation \#4 } \\
\text { (Building 90002) }\end{array}$ & $1.1 \mathrm{E}-11$ & $2.8 E-10$ & $1.1 \mathrm{E}-07$ & $1.6 \mathrm{E}-09$ & $4.9 \mathrm{E}-15$ & $1.5 \mathrm{E}-12$ & $7.4 \mathrm{E}-10$ & $1.6 \mathrm{E}-12$ & $1.3 \mathrm{E}-06$ & $1.9 \mathrm{E}-12$ \\
\hline KAFB Landfill & $1.4 \mathrm{E}-10$ & $2.3 \mathrm{E}-09$ & $1.7 \mathrm{E}-06$ & 4.4E-07 & $2.8 \mathrm{E}-14$ & $2.2 \mathrm{E}-11$ & $2.0 \mathrm{E}-08$ & $4.3 \mathrm{E}-11$ & $1.0 \mathrm{E}-06$ & $3.4 \mathrm{E}-12$ \\
\hline KUMSC & $4.6 \mathrm{E}-11$ & $1.2 \mathrm{E}-09$ & 4.7E-07 & $4.5 \mathrm{E}-08$ & $1.8 \mathrm{E}-14$ & $4.8 \mathrm{E}-12$ & 3.1E-09 & $7.6 \mathrm{E}-12$ & $4.0 \mathrm{E}-06$ & $3.2 \mathrm{E}-11$ \\
\hline Loop Housing & $8.4 \mathrm{E}-10$ & $2.1 \mathrm{E}-08$ & $5.2 \mathrm{E}-06$ & $1.7 \mathrm{E}-06$ & $2.2 \mathrm{E}-13$ & $2.7 \mathrm{E}-11$ & $2.2 \mathrm{E}-08$ & $2.8 \mathrm{E}-11$ & $6.1 \mathrm{E}-07$ & $1.7 \mathrm{E}-12$ \\
\hline Manzano Offices (Fire Station) & $1.4 \mathrm{E}-11$ & $3.5 \mathrm{E}-10$ & $2.4 \mathrm{E}-07$ & $2.0 \mathrm{E}-08$ & $5.7 \mathrm{E}-15$ & $3.6 \mathrm{E}-12$ & $1.8 \mathrm{E}-09$ & $3.0 \mathrm{E}-12$ & $1.3 \mathrm{E}-06$ & 4.3E-12 \\
\hline Maxwell Housing & $6.5 \mathrm{E}-11$ & $1.7 \mathrm{E}-09$ & $6.2 \mathrm{E}-07$ & $5.7 \mathrm{E}-08$ & $2.7 \mathrm{E}-14$ & $7.5 \mathrm{E}-12$ & 3.1E-09 & $6.7 \mathrm{E}-12$ & 8.7E-07 & $2.3 \mathrm{E}-12$ \\
\hline Pershing Park Housing & $3.1 \mathrm{E}-10$ & 7.9E-09 & $2.6 \mathrm{E}-06$ & $5.0 \mathrm{E}-07$ & $1.1 \mathrm{E}-13$ & $1.8 \mathrm{E}-11$ & $1.2 \mathrm{E}-08$ & $1.9 \mathrm{E}-11$ & $5.3 \mathrm{E}-07$ & $1.4 \mathrm{E}-12$ \\
\hline Riding Club & $2.8 \mathrm{E}-11$ & $7.0 \mathrm{E}-10$ & $3.1 E-07$ & 3.1E-08 & $1.1 \mathrm{E}-14$ & $4.6 \mathrm{E}-12$ & 2.7E-08 & $6.4 \mathrm{E}-12$ & $1.6 \mathrm{E}-06$ & $6.9 \mathrm{E}-12$ \\
\hline Sandia Federal Credit Union & $1.8 \mathrm{E}-09$ & $5.9 \mathrm{E}-08$ & 7.7E-06 & $5.2 \mathrm{E}-06$ & $3.3 \mathrm{E}-13$ & $3.6 \mathrm{E}-11$ & $3.0 \mathrm{E}-08$ & $3.5 \mathrm{E}-11$ & $7.0 \mathrm{E}-07$ & $2.0 \mathrm{E}-12$ \\
\hline TOSI Facility & $3.1 \mathrm{E}-10$ & $9.2 \mathrm{E}-09$ & $2.4 \mathrm{E}-06$ & $6.0 \mathrm{E}-07$ & $8.0 \mathrm{E}-14$ & $3.0 \mathrm{E}-11$ & $2.4 \mathrm{E}-09$ & $8.4 \mathrm{E}-11$ & $9.8 \mathrm{E}-07$ & $3.0 \mathrm{E}-12$ \\
\hline Zia Park Housing & $3.6 \mathrm{E}-10$ & $1.0 \mathrm{E}-08$ & $2.6 \mathrm{E}-06$ & $7.2 \mathrm{E}-07$ & $1.6 \mathrm{E}-13$ & $2.4 \mathrm{E}-11$ & $1.4 \mathrm{E}-08$ & $2.1 \mathrm{E}-11$ & $9.1 \mathrm{E}-07$ & $2.4 \mathrm{E}-12$ \\
\hline
\end{tabular}


Table 1b. Annual Effective Dose Equivalent to On-Site Receptors (Concluded)

\begin{tabular}{|c|c|c|c|c|c|c|c|}
\hline \multirow[b]{2}{*}{ Receptor } & \multicolumn{6}{|c|}{ Source-Specific Effective Dose Equivalents (mrem/yr) } & \multirow{2}{*}{$\begin{array}{l}\text { Effective } \\
\text { Dose } \\
\text { Equivalent } \\
\text { (mrem/yr) }\end{array}$} \\
\hline & $\begin{array}{c}\text { RMWMF } \\
\text { (Bldg. 6920) }\end{array}$ & $\begin{array}{l}\text { HERMES III } \\
\text { (Bldg. 970) }\end{array}$ & $\begin{array}{c}\text { PBFA II } \\
\text { (Bldg. 983) }\end{array}$ & $\begin{array}{l}\text { Hot Cell } \\
\text { Facility }\end{array}$ & $\begin{array}{c}\text { ACRR } \\
\text { (Bldg. 6588) }\end{array}$ & $\begin{array}{c}\text { SPR } \\
\text { (Bldg. 6590) }\end{array}$ & \\
\hline Airport (Building 760) & $6.0 \mathrm{E}-06$ & $3.4 \mathrm{E}-09$ & $4.5 \mathrm{E}-07$ & $1.0 \mathrm{E}-04$ & 8.9E-04 & 1.4E-04 & 1.2E-03 \\
\hline Airport East (Building 1064) & $5.1 \mathrm{E}-06$ & 2.3E-09 & $3.6 \mathrm{E}-07$ & $5.1 \mathrm{E}-05$ & 4.3E-04 & $1.1 \mathrm{E}-04$ & $6.0 \mathrm{E}-04$ \\
\hline Building 20706 & 4.3E-06 & $1.8 \mathrm{E}-08$ & $2.6 \mathrm{E}-06$ & $6.6 \mathrm{E}-05$ & $6.0 \mathrm{E}-04$ & $1.5 \mathrm{E}-04$ & 8.3E-04 \\
\hline Building 24499 & $3.7 \mathrm{E}-06$ & $4.5 \mathrm{E}-09$ & $5.7 \mathrm{E}-07$ & 4.3E-05 & $3.8 \mathrm{E}-04$ & $9.4 \mathrm{E}-05$ & $5.3 \mathrm{E}-04$ \\
\hline CERF (Building 5701) & $8.4 \mathrm{E}-06$ & $1.4 \mathrm{E}-10$ & $2.0 \mathrm{E}-08$ & $3.6 \mathrm{E}-05$ & 3.7E-04 & $9.2 \mathrm{E}-05$ & $5.1 \mathrm{E}-04$ \\
\hline Coyote Canyon Control Center & $7.6 \mathrm{E}-06$ & $9.4 \mathrm{E}-11$ & $2.2 \mathrm{E}-08$ & 3.6E-05 & 3.7E-04 & $9.2 \mathrm{E}-05$ & $5.1 \mathrm{E}-04$ \\
\hline Golf Course Clubhouse & $8.8 \mathrm{E}-06$ & $5.0 \mathrm{E}-09$ & $7.5 \mathrm{E}-07$ & $1.9 \mathrm{E}-04$ & $2.2 \mathrm{E}-03$ & 4.8E-04 & $2.9 \mathrm{E}-03$ \\
\hline Golf Course Maintenance Area & 7.3E-06 & 8.3E-09 & $1.9 \mathrm{E}-06$ & $1.2 \mathrm{E}-04$ & $1.4 \mathrm{E}-03$ & 3.3E-04 & $1.9 \mathrm{E}-03$ \\
\hline ITRI/Lovelace & $7.8 \mathrm{E}-06$ & $8.5 \mathrm{E}-11$ & $1.2 \mathrm{E}-08$ & $3.2 \mathrm{E}-05$ & 2.8E-04 & $7.2 \mathrm{E}-05$ & $3.9 \mathrm{E}-04$ \\
\hline KAFB Firestation \#4 (Building 90002) & $1.5 \mathrm{E}-05$ & $2.9 \mathrm{E}-11$ & 3.7E-09 & $4.5 \mathrm{E}-05$ & 4.1E-04 & $1.0 \mathrm{E}-04$ & 5.7E-04 \\
\hline KAFB Landfill & $5.4 \mathrm{E}-06$ & 4.1E-08 & 4.7E-06 & $7.6 \mathrm{E}-05$ & $7.7 \mathrm{E}-04$ & $1.9 \mathrm{E}-04$ & $1.0 \mathrm{E}-03$ \\
\hline KUMSC & $1.4 \mathrm{E}-05$ & $2.0 \mathrm{E}-09$ & $3.3 E-07$ & $3.9 \mathrm{E}-04$ & $5.4 \mathrm{E}-03$ & $1.2 \mathrm{E}-03$ & $7.0 \mathrm{E}-03$ \\
\hline Loop Housing & $3.6 \mathrm{E}-06$ & $5.4 \mathrm{E}-09$ & $7.4 \mathrm{E}-07$ & 4.1E-05 & $3.6 \mathrm{E}-04$ & $9.0 \mathrm{E}-05$ & $5.0 \mathrm{E}-04$ \\
\hline Manzano Offices (Fire Station) & 8.7E-06 & $5.9 \mathrm{E}-10$ & $8.4 \mathrm{E}-08$ & $1.0 \mathrm{E}-04$ & $1.1 \mathrm{E}-03$ & $2.6 \mathrm{E}-04$ & $1.5 \mathrm{E}-03$ \\
\hline Maxwell Housing & $4.2 \mathrm{E}-06$ & $5.8 \mathrm{E}-10$ & $8.6 \mathrm{E}-08$ & $6.1 \mathrm{E}-05$ & 4.7E-04 & $1.2 \mathrm{E}-04$ & $6.6 \mathrm{E}-04$ \\
\hline Pershing Park Housing & $3.3 \mathrm{E}-06$ & 2.7E-09 & $3.7 \mathrm{E}-07$ & 4.5E-05 & 3.7E-04 & $7.5 \mathrm{E}-05$ & $5.0 \mathrm{E}-04$ \\
\hline Riding Club & $1.0 \mathrm{E}-05$ & $1.2 \mathrm{E}-09$ & $2.8 \mathrm{E}-07$ & $1.6 \mathrm{E}-04$ & $2.0 \mathrm{E}-03$ & $4.5 \mathrm{E}-04$ & $2.6 \mathrm{E}-03$ \\
\hline Sandia Federal Credit Union & $4.0 \mathrm{E}-06$ & $1.0 \mathrm{E}-08$ & $1.5 \mathrm{E}-06$ & $5.9 \mathrm{E}-05$ & $5.2 \mathrm{E}-04$ & $1.3 \mathrm{E}-04$ & 7.3E-04 \\
\hline TOSI Facility & $5.1 \mathrm{E}-06$ & 7.1E-08 & $2.2 \mathrm{E}-05$ & $8.4 \mathrm{E}-05$ & $8.0 \mathrm{E}-04$ & $1.9 \mathrm{E}-04$ & $1.1 \mathrm{E}-03$ \\
\hline Zia Park Housing & $5.5 \mathrm{E}-06$ & $5.0 \mathrm{E}-09$ & $7.9 \mathrm{E}-07$ & $5.8 \mathrm{E}-05$ & $5.0 \mathrm{E}-04$ & $1.3 \mathrm{E}-04$ & $7.0 \mathrm{E}-04$ \\
\hline
\end{tabular}


Table 2. Annual Effective Dose Equivalent to On-Site Receptors

\begin{tabular}{|c|c|c|c|c|c|c|}
\hline \multirow[b]{2}{*}{ Receptor } & \multicolumn{6}{|c|}{ Source-Specific Effective Dose Equivalents (mrem/yr) } \\
\hline & $\begin{array}{c}\text { Hot Cell } \\
\text { Facility } \\
\text { (Bldg. 6580) }\end{array}$ & $\begin{array}{c}\text { ACRR } \\
\text { (Bldg. 6588) }\end{array}$ & $\begin{array}{c}\text { SPR } \\
\text { (Bldg. 6590) }\end{array}$ & $\begin{array}{l}\text { Effective } \\
\text { Dose } \\
\text { Equivalent } \\
\text { (mrem/yr) } \\
3 \text { sources }\end{array}$ & $\begin{array}{c}\text { Effective } \\
\text { Dose } \\
\text { Equivalent } \\
\text { (mrem/yr) } \\
16 \text { sources }\end{array}$ & $\begin{array}{c}\% \\
\text { Difference }\end{array}$ \\
\hline Airport (Building 760) & $1.0 \mathrm{E}-04$ & $8.9 \mathrm{E}-04$ & $1.4 \mathrm{E}-04$ & $1.1 \mathrm{E}-03$ & $1.2 \mathrm{E}-03$ & 8.3 \\
\hline Airport East (Building 1064) & $5.1 \mathrm{E}-05$ & 4.3E-04 & $1.1 \mathrm{E}-04$ & $5.9 \mathrm{E}-04$ & $6.0 \mathrm{E}-04$ & 1.7 \\
\hline Building 20706 & $6.6 \mathrm{E}-05$ & $6.0 \mathrm{E}-04$ & $1.5 \mathrm{E}-04$ & 8.2E-04 & 8.3E-04 & 1.2 \\
\hline Building 24499 & 4.3E-05 & $3.8 \mathrm{E}-04$ & $9.4 \mathrm{E}-05$ & $5.2 \mathrm{E}-04$ & $5.3 E-04$ & 1.9 \\
\hline CERF (Building 5701) & $3.6 \mathrm{E}-05$ & $3.7 \mathrm{E}-04$ & $9.2 \mathrm{E}-05$ & $5.0 \mathrm{E}-04$ & $5.1 \mathrm{E}-04$ & 2.0 \\
\hline Coyote Canyon Control Center & $3.6 \mathrm{E}-05$ & $3.7 \mathrm{E}-04$ & $9.2 \mathrm{E}-0.5$ & $5.0 \mathrm{E}-04$ & 5.1E-04 & 2.0 \\
\hline Golf Course Clubhouse & $1.9 \mathrm{E}-04$ & 2.2E-03 & 4.8E-04 & 2.9E-03 & 2.9E-03 & 0.0 \\
\hline Golf Course Maintenance Area & 1.2E-04 & $1.4 \mathrm{E}-03$ & $3.3 \mathrm{E}-04$ & $1.9 \mathrm{E}-03$ & $1.9 \mathrm{E}-03$ & 2.6 \\
\hline ITRI/Lovelace & $3.2 \mathrm{E}-05$ & $2.8 \mathrm{E}-04$ & 7.2E-05 & $3.8 \mathrm{E}-04$ & $3.9 \mathrm{E}-04$ & 2.6 \\
\hline KAFB Firestation \#4 (Building 90002) & $4.5 \mathrm{E}-05$ & 4.1E-04 & $1.0 \mathrm{E}-04$ & $5.6 \mathrm{E}-04$ & $5.7 \mathrm{E}-04$ & 1.8 \\
\hline KAFB Landfill & $7.6 \mathrm{E}-05$ & 7.7E-04 & $1.9 \mathrm{E}-04$ & $1.0 \mathrm{E}-03$ & $1.0 \mathrm{E}-03$ & 0.0 \\
\hline KUMSC & $3.9 \mathrm{E}-04$ & $5.4 \mathrm{E}-03$ & 1.2E-03 & $7.0 \mathrm{E}-03$ & $7.0 \mathrm{E}-03$ & 0.0 \\
\hline Loop Housing & 4.1E-05 & $3.6 \mathrm{E}-04$ & $9.0 \mathrm{E}-05$ & $4.9 \mathrm{E}-04$ & $5.0 \mathrm{E}-04$ & 2.0 \\
\hline Manzano Offices (Fire Station) & $1.0 \mathrm{E}-04$ & $1.1 \mathrm{E}-03$ & $2.6 \mathrm{E}-04$ & $1.5 \mathrm{E}-03$ & $1.5 \mathrm{E}-03$ & 2.7 \\
\hline Maxwell Housing & $6.1 \mathrm{E}-05$ & 4.7E-04 & $1.2 \mathrm{E}-04$ & $6.5 \mathrm{E}-04$ & $6.6 \mathrm{E}-04$ & 1.5 \\
\hline Pershing Park Housing & $4.5 \mathrm{E}-05$ & $3.7 \mathrm{E}-04$ & $7.5 \mathrm{E}-05$ & $4.9 \mathrm{E}-04$ & $5.0 \mathrm{E}-04$ & 2.0 \\
\hline Riding Club & $1.6 \mathrm{E}-04$ & $2.0 \mathrm{E}-03$ & $4.5 \mathrm{E}-04$ & $2.6 \mathrm{E}-03$ & $2.6 \mathrm{E}-03$ & 0.0 \\
\hline Sandia Federal Credit Union & $5.9 \mathrm{E}-05$ & $5.2 \mathrm{E}-04$ & $1.3 \mathrm{E}-04$ & $7.1 \mathrm{E}-04$ & $7.3 \mathrm{E}-04$ & 2.7 \\
\hline TOSI Facility & $8.4 \mathrm{E}-05$ & $8.0 \mathrm{E}-04$ & $1.9 \mathrm{E}-04$ & $1.1 \mathrm{E}-03$ & $1.1 \mathrm{E}-03$ & 0.0 \\
\hline Zia Park Housing & $5.8 \mathrm{E}-05$ & $5.0 \mathrm{E}-04$ & $1.3 \mathrm{E}-04$ & $6.9 \mathrm{E}-04$ & $7.0 \mathrm{E}-04$ & 1.4 \\
\hline
\end{tabular}

